\title{
Decrease in the number of farms in the State of Paraná, Brazil
}

\section{Queda no número de empreendimentos agrícolas do Estado do Paraná, Brasil}

\author{
Tiago Santos Telles ${ }^{1 *}$; Gustavo Vaz da Costa ${ }^{2}$; Gustavo Henrique Leite de Castro ${ }^{1}$; \\ Matheus Demambre Bacchi ${ }^{3}$; Antonio Carlos Laurenti ${ }^{1}$
}

\begin{abstract}
Issues related to farms have begun to be discussed in a global context due to their importance in the economic development process, as they have a direct impact on the social transformations within and away from the countryside and are an important part of the system ensuring the food supply and food security for the population. Thus, the aim of this study was to characterize the trends in the number of farms in the rural areas of Paraná, Brazil, by main type of activity and by land size category for the period from 2002 to 2014. Data from the National Household Sample Survey were used, and the mean annual variation rates were calculated via Student's $t$-test using a log-linear ordinary least squares regression model. A reduction of $3.5 \%$ per annum (pa) was seen in the number of farms, both in relation to main activities and land size. There was a sharper decline in the number of farms dedicated to soybean $(8.9 \% \mathrm{pa})$ and corn $(6.3 \% \mathrm{pa})$ production and in the number of farms ranging in size from 10 ha to $<100$ ha of land $(7.09 \% \mathrm{pa})$. This information may support the establishment of public actions focused on the farming sector in Paraná. Key words: PNAD. Employer. Self-employed. Agricultural activity. Area division.
\end{abstract}

\section{Resumo}

As questões relacionadas aos empreendimentos agrícolas vêm sendo discutidas em um contexto global, o que se deve à sua importância no processo de desenvolvimento econômico, uma vez que eles possuem impactos diretos nas transformações sociais dentro e fora do campo, além de ser parte importante no sistema de garantia do abastecimento e da segurança alimentar da população. Assim, o objetivo deste estudo foi caracterizar as tendências de variação no número de empreendimentos agrícolas no meio rural paranaense, por tipo de atividade principal e por estrato de área, para o período de 2002 a 2014. Para tanto, foram utilizados dados da Pesquisa Nacional por Amostra de Domicílios e calculadas as taxas médias de variação anual, por meio do teste $t$ de Student, utilizando-se uma regressão dos mínimos quadrados ordinários na forma log-linear. Verificou-se redução de 3,5\% a.a. no número de empreendimentos agropecuários, tanto com relação às atividades principais, quanto para os extratos de área. Houve queda mais intensa no número de empreendimentos dedicados a soja ( $8,9 \%$ a.a.) e milho ( $6,3 \%$ a.a.) e naqueles de 10 ha a $<100$ ha (7,09\% a.a.). Essas informações podem subsidiar o delineamento de ações públicas voltadas

1 Pesquisadores, Área de Socioeconomia, Instituto Agronômico do Paraná, IAPAR, Londrina, PR, Brasil. E-mail: telles@iapar.br; castro.guh@gmail.com; laurenti@iapar.br

2 Discente de Mestrado, Programa de Pós-Graduação em Agronomia, Universidade Estadual de Londrina, UEL, Londrina, PR, Brasil. E-mail: gustavo.vaz.costa@gmail.com

3 Discente de Mestrado, Programa de Pós-Graduação em Economia Aplicada, Universidade de São Paulo, Escola Superior de Agricultura “Luiz de Queiroz”, USP-ESALQ, Piracicaba, SP. E-mail: matheusbacchi@yahoo.com.br

" Author for correspondence 
à agropecuária paranaense.

Palavras-chave: PNAD. Empregador. Conta própria. Atividade agrícola. Estrato de área.

\section{Introduction}

Between 1970 and 2010, the rural population in Brazil fell from $44.0 \%$ to $15.6 \%$ of the total population, revealing the speed of urbanization in the country; nonetheless, in absolute terms, the size of the Brazilian rural population continues to be significant, amounting to over 30 million people in 2010 (MAIA; BUAINAIN, 2015). Starting in the 2000s, studies began investigating the population dynamics related to people employed in the rural environment in Brazil (NEDER, 2008; BALSADI, 2009; BUAINAIN; DEDECCA, 2010; PRONI, 2010; SAKAMOTO; MAIA, 2012; STADUTO et al., 2013; MATTEI, 2015; LAURENTI et al., 2015; BALSADI; DEL GROSSI, 2016). In general, the results indicated a reduction in the rural economically active population (EAP) engaged in agricultural activity and an increase in the rural EAP engaged in non-agricultural activity. The main explanation for these findings was agricultural modernization, which led to significant changes in the mode of production, with emphasis on the mechanization of production through labor-saving technologies that require hiring more skilled individuals (FERREIRA et al., 2006; DEL GROSSI; GRAZIANO DA SILVA, 2006).

In the South, the trends observed with regard to the EAP were the same as for Brazil as a whole (BALSADI; DEL GROSSI, 2016; BALSADI, 2017; TELLES et al., 2017). According to Telles et al. (2017), there was a decline in the total employed rural EAP, in absolute terms, as 108,000 people left rural employment in the South between 2001 and 2009. The study also showed that the rural EAP engaged in agricultural activity is declining by approximately $2.6 \%$ per annum (pa) and the rural EAP engaged in non-agricultural activity is increasing by approximately $4.1 \%$ pa. According to Balsadi and Del Grossi (2016), between 2004 and 2014 , there was a reduction of $4.2 \%$ pa in the agricultural EAP; ${ }^{4}$ that is, 933,000 people ceased to be engaged in agricultural activities.

In the case of the state of Paraná, several studies have analyzed the population dynamics related to people employed in the rural environment (BAZOTTI et al., 2009; LAURENTI, 2013; COSTA JUNIOR; BACHA, 2016; BALSADI, 2017). Using data from the National Household Sample Survey (Pesquisa Nacional por Amostra de Domicílios PNAD) or the Demographic Census sourced from the Brazilian Institute of Geography and Statistics (Instituto Brasileiro de Geografia e Estatística IBGE), most of the studies recognize the continuous decline in the rural EAP engaged in agricultural activity and the growth of the rural EAP engaged in non-agricultural activity. According to Balsadi (2017), between 2000 and 2014 there was a decline in the rural EAP engaged in agricultural activity approximately 346,000 people ceased to be engaged in any agricultural activity - and an increase in the rural EAP engaged in non-agricultural activity approximately 97,000 people came to exercise some form of non-agricultural activity.

Given that the reduction in the number of people employed in rural areas of Paraná certainly did not occur uniformly, to better understand recent changes in the rural environment, it is important to analyze changes in farms. This is because, in a context of decreasing agricultural EAP, one of the issues raised is whether this decrease is due to a reduction in the number of farms. However, even with the vast literature on this subject, there is a lack of studies emphasizing the trends in the number of farms (NEY; HOFFMANN, 2003, 2008; HOFFMANN;

${ }_{4}$ The agricultural EAP is the sum of the rural EAP engaged in agricultural activity and the urban EAP engaged in agricultural activity. 
NEY, 2010; HOFFMANN, 2011). Thus, the problem involves determining the changes in the number of agricultural enterprises in Paraná, by main activity and land size. In other words, the idea is to identify in which activities there was an increase or decrease in the number of farms as well as the intensity of this variation. The dynamics of the number of farms by land size will also be determined.

The characterizations of these trends can, in particular, support both the formulation and the evaluation of public policies directed toward the rural environment.

In this context, the aim of the present study was to characterize the trends in the number of farms in Paraná, by main activity and by land size, from 2002 to 2014.

\section{Materials and Methods}

With the aim of ascertaining the trends in the number of farms in Paraná, the IBGE's microdata database from the PNAD was used for the years 2002 to 2014. The use of the PNAD as a database is justified because its periodicity is annual, which allows the calculation of annual compound growth rates (over a period of time). Additionally, the PNAD better captures the land size of farms belonging to private individuals (HOFFMANN; NEY, 2010).

For each household sampled by the PNAD, information was requested and recorded about the land size of the farms exploited by the person whose occupation during the reference week of the study was either self-employed or employer and who exercised a main (or only) activity in agriculture, forestry, or breeding of cattle, buffaloes, goats, sheep, or pigs.
Furthermore, in the PNAD, if there were two or more people in a household acting as selfemployed or employer in the same agricultural enterprise, the associated exploited land size could be recorded more than once. To avoid this problem, the data were filtered, excluding the "spouses" and "children" whose declared land size was the same as the "reference person" of the household.

To obtain a more coherent dataset about the farms of the PNAD, in accordance with Hoffmann (2011), the cases of self-employed individuals and employers declaring land sizes $\leq 0.1$ hectare (ha) or $>10,000$ ha were excluded from the estimates.

To define the main activity of the farms, the PNAD uses the categories of the National Classification of Economic Activities (Classificação Nacional de Atividades Econômicas - CNAE), classifying the farms according to the "code of the main activity of the farms in the reference week."

The main activities of the farms considered in this study were those most frequent in the PNAD of 2014: cattle, corn, soybeans, vegetables, tobacco, other temporary crops, coffee, and other (cassava, mixture of crops and livestock, rice, other cereals, cotton, sugarcane, flowers and ornamental plants, citrus fruits, cacao, grape, banana, other plants and fruits, seeds and seedlings, unspecified crops, rearing of large unspecified animals, goats and sheep, pigs, poultry, apiculture, sericulture, other unspecified animals, unspecified livestock, forestry, fishing and aquaculture).

For the present study, three land size intervals were defined, in hectares (ha), following the same standard adopted by Hoffmann and Ney (2010): (i) $\geq 0.1$ to $<10$, (ii) $\geq 10$ to $<100$, and (iii) $\geq 100$.

\footnotetext{
5 The year 2010 was not considered because the Demographic Census was conducted rather than the PNAD.

6 The "self-employed" category refers to individuals who are engaged in their own enterprises, performing economic activities without employees, either individually or with partners, with or without the aid of non-remunerated workers. The «employer» category includes individuals who are engaged in their own enterprises, performing economic activities either individually or with partners, and with at least one employee.
} 
The trends in the number of farms per main activity were characterized based on the mean annual compound variation rate, calculated based on the antilogarithm of the slope of the log-linear equation, via the ordinary least squares (OLS) regression method, which correlates the estimated number of existing farms to the corresponding year of observation, as per Equation 1 (GREENE, 2008). This rate of change was expressed as a percentage, with the acceptability of the hypotheses assessed by Student's $t$-test, considering levels of significance of 1,5 , and $10 \%$.

$$
\ln Y_{i}=\alpha+\beta X_{i}+\mu_{i} \quad i=1,2, \ldots, n
$$

where $\alpha$ is the intercept, $\beta$ is the slope of the line, $X$ is the explanatory variable referring to the year corresponding to the $i^{\text {th }}$ observation, $Y$ is the dependent variable referring to the main activity and land size category in the $i^{\text {th }}$ year, $\mu$ is the random error, and $i$ is the number of years.

To evaluate the degree of concentration of farms in Paraná, the Hirschman-Herfindahl index (HHI) was used. The HHI refers to the sum of the squares of a firm's market share in an industry (HIRSCHMAN, 1964). This share can be analyzed through any variable that can represent it. In the case of this study, the share of the farms in Paraná is used to verify if there is a concentration in this segment and to verify the change in this index in the years analyzed. Thus, we have the following:

$$
H H I=\sum_{i=1}^{k}(P i)^{2}
$$

where $k$ represents the number of land area categories in Paraná, and $P i$ is the market share, in percentage, for each $i$ land size category in Paraná.
The representation indicates the weights of this indicator when squaring each farm's market share, i.e., higher concentrations are attributed to markets with smaller numbers of farms; therefore, the higher the HHI value, the higher the market concentration level and the lower the market competitiveness (BOFF; RESENDE, 2002).

The HHI index varies between " $1 \mathrm{n}^{-1}$ " and " 1 ", where the minimum value of " $1 \mathrm{n}^{-1}$ " can reach zero, in the case of perfect competition with a large number of farms participating in the market. By contrast, the maximum value of the index is associated with a monopolistic situation, in which a single firm captures all of the market share. Resende (1994) argued the following: if the index is less than 0.1 , the marketplace is not very concentrated; if it is between 0.1 and 0.18 , the marketplace has a moderate degree of concentration; and, finally, if the index is higher than 0.18 , the marketplace is very concentrated.

The data were processed and analyzed using IBM SPSS ${ }^{\circledR}$ Statistics 22.0.

\section{Results and Discussion}

There was a reduction in the mean annual growth rates of the rural EAP engaged in agricultural activities, in accordance with the occupation and main activity group, in both the "employed (broad)" and the "employed (restricted)" categories (Table 1). This reduction was more pronounced for the non-remunerated workers situated in the "employed (broad)" category and for the employers within the "employed (restricted)" category.

\footnotetext{
7 According to the definition of economically active population used in the PNAD before the change in the concept of work, which occurred in 1992
} 
Table 1. Distribution of the individuals employed in agriculture and living in rural areas in Paraná, according to occupation, ${ }^{1}$ and mean annual growth rate in the period between 2002 and 2014 (in thousands).

\begin{tabular}{lccccccccccccc}
\hline Occupation & 2002 & 2003 & 2004 & 2005 & 2006 & 2007 & 2008 & 2009 & 2011 & 2012 & 2013 & 2014 & $i^{2}$ \\
\hline Non-remunerated worker & 31 & 34 & 38 & 36 & 27 & 51 & 36 & 27 & 16 & 16 & 5 & 20 & $-10.10^{* *}$ \\
Self-consumption & 105 & 118 & 106 & 138 & 144 & 127 & 130 & 116 & 125 & 89 & 79 & 94 & $-2.3^{*}$ \\
Employed (restricted) & 627 & 636 & 604 & 572 & 554 & 515 & 482 & 467 & 389 & 352 & 342 & 348 & $-5.7^{* * *}$ \\
$\quad$ Worker & 429 & 440 & 415 & 370 & 449 & 307 & 266 & 312 & 232 & 223 & 206 & 202 & $-7.0^{* * *}$ \\
$\quad$ Employer & 7 & 8 & 16 & 14 & 11 & 9 & 9 & 8 & 4 & 7 & 4 & 1 & $-9.2^{* * *}$ \\
$\quad$ Self-employed & 191 & 188 & 174 & 188 & 175 & 198 & 207 & 147 & 153 & 123 & 132 & 145 & $-3.2^{* * *}$ \\
Total (employed (broad)) & 763 & 788 & 748 & 745 & 726 & 692 & 648 & 610 & 531 & 457 & 426 & 462 & $-5.2^{* * *}$ \\
\hline
\end{tabular}

Source: Based on the microdata of the National Household Sample Survey (PNAD) of the Brazilian Institute of Geography and Statistics (IBGE).

Notes: ${ }^{1}$ According to code variable V9008 from the dictionary of variables of the PNAD, relative to the occupation of the person in the main job. ${ }^{2}$ Mean annual growth rate in percentage. Corresponds to the estimated coefficient of a log-linear regression against time. In this case, the $t$-test reveals whether there are trends in the data. $* * *$ indicates a level of significance of $1 \%$. $* *$ indicates a level of significance of $5 \%$ and $*$ indicates a level of significance of $10 \%$. ${ }^{3}$ Person employed without remuneration in money, products, or services, with a weekly workload of up to 15 hours in the main and/or secondary job. ${ }^{4}$ According to the definition of economically active population used in the PNAD before the change in the concept of work, which occurred in 1992.

The results observed in Table 1 show a similarity and continuity in the decrease of the employed rural population measured by Laurenti (2013); that is, there was a decline of $5.2 \%$ pa in the employed rural EAP. According to Mattei (2015), the agricultural EAP has been decreasing in recent decades, with a direct effect on employment in rural areas. Between 2002 and 2013, 500,000 people ceased to be a part of a total of 4 million people who were employed in agricultural activities.

According to Proni (2010), one of the explanations for the reduction in the agricultural rural EAP is that there are places where the rural population is extremely vulnerable, areas where precarious working relationships prevail, given that: (i) there is a large number of individuals classified as "reserve agricultural army" (i.e., they are rural workers who are on the margins of mercantile relations); (ii) some of those who are employed are subjected to excessive working hours and low monthly income levels; and (iii) with the development and intensification of mechanization in agriculture, many individuals cannot get work because they do not have suitable skills. These issues, in turn, generate an increasing disinterest among the rural EAP with regard to engaging in agricultural activities.

The category exhibiting the greatest decrease during the period was that of employer, with $9.2 \%$ pa. One of the plausible explanations is a decrease in the number of farms due to landholding concentration; that is, an increase in the land size of the farms due to a reduction in the number of farms. Another possible explanation is the change in category over the years (employers becoming self-employed), and such a transformation could have led to a decline in the number of employees of approximately $7 \%$ pa, given that, in order to be classified in the "employer" category, the individual must have at least one employee.

These population categories have already been studied for the years 2001 to 2009 by Laurenti (2013) for Paraná, by Telles et al. (2017) for the major regions of Brazil, and by Laurenti et al. (2015) for Brazil as a whole. The trends observed in the present study and in the studies mentioned are decreases in the rural population in general and in the population of non-remunerated workers in particular. However, the same cannot be said about 
those who produce for their own consumption. Whereas in the previous studies there was growth of the population in this category (especially after 2006), here there is a significant reduction.

Thus, the choice to focus on the employer and self-employed categories for the analysis conducted in this study was made not only because, according to the IBGE, these categories are the only ones with land destined to farms but also because they constitute a significant percentage of the employed rural EAP. The relative share of the "employer" and "self-employed" categories in the composition of the employed rural EAP was approximately 25 to $32 \%$ during the years considered in the present study. Therefore, the analyses refer to the "employer" and "self-employed" categories of the employed rural EAP.

With regard to the distribution of the most frequent main activities in the farms, all those with land sizes between 0.1 ha and 10,000 ha are shown in Table 2.

Table 2. Distribution of the most frequent agricultural activities in the employer and self-employed farms in rural areas of Paraná, in the period from 2002 to 2014 (in thousands of farms).

\begin{tabular}{lccccccccccccc}
\hline Main activity & 2002 & 2003 & 2004 & 2005 & 2006 & 2007 & 2008 & 2009 & 2011 & 2012 & 2013 & 2014 & $i^{3}$ \\
\hline Cattle & 27 & 25.9 & 33.4 & 46.5 & 47 & 50.9 & 46.6 & 36.1 & 41.9 & 39.7 & 46.1 & 52.1 & $3.753^{* *}$ \\
Corn & 36.5 & 38.9 & 30.9 & 33.3 & 14 & 33.4 & 32 & 20.5 & 19.1 & 14.9 & 16.9 & 20.4 & $-6.332^{* * *}$ \\
Soybeans & 44.8 & 40.7 & 42.4 & 34 & 32.7 & 30.4 & 34.8 & 29.8 & 10.1 & 18 & 21.8 & 16.5 & $-8.898^{* * *}$ \\
Vegetables & 13.2 & 44.6 & 9.7 & 11.4 & 11.1 & 19 & 6.5 & 10.2 & 8 & 7.9 & 12.5 & 10.8 & $-5.439^{\text {NS }}$ \\
Tobacco & 13.3 & 13.3 & 13.6 & 16.7 & 18.7 & 15.5 & 15.4 & 13.8 & 9.3 & 11 & 7.4 & 9.5 & $-4.641^{* *}$ \\
Other crops $^{1}$ & 34.6 & 9.1 & 32.7 & 30.3 & 34.6 & 21.5 & 32.9 & 14.5 & 9.1 & 5.2 & 2 & 5.9 & $-16.172^{* * *}$ \\
Coffee $^{2}$ & 6.7 & 4.9 & 5.4 & 5.4 & 6.6 & 6.8 & 9 & 4.4 & 7.1 & 2.7 & 4.7 & 4.6 & $-2.900^{\text {NS }}$ \\
Other $^{2}$ & 22 & 18.7 & 21.4 & 24.4 & 21.3 & 29.8 & 38.9 & 26.3 & 52.6 & 29.7 & 24.4 & 26.2 & $3.627^{*}$ \\
Total $^{198}$ & 196 & 189 & 202 & 186 & 207 & 216 & 155 & 157 & 129 & 135 & 146 & $-3.538^{* * *}$ \\
\hline
\end{tabular}

Source: Based on the microdata of the National Household Sample Survey (PNAD) of the Brazilian Institute of Geography and Statistics (IBGE).

Notes: ${ }^{1}$ Other temporary crops. ${ }^{2}$ Rice, cassava, other cereals, cotton, sugarcane, flowers and ornamental plants, citrus fruits, cocoa, grapes, banana, other plants and fruits, seeds and seedlings, unspecified crops, rearing of large unspecified animals, goats and sheep, pigs, poultry, apiculture, sericulture, other unspecified animals, forestry, fishing and aquaculture. In accordance with the composition of the groupings of activities and the list of activity codes from the National Classification of Economic Activities (CNAE - Household) - in this case, the term "agriculture" also covers cattle raising. CNAE - Household, in addition to containing the mixed activity of crops and cattle raising. ${ }^{3}$ Mean annual growth rate expressed as a percentage. Corresponds to the estimated coefficient of a log-linear regression against time. In this case, the $t$-test reveals whether there are trends in the data. *** indicates a significance level of $1 \%, * *$ indicates a significance level of $5 \%$, and * indicates a significance level of $10 \%$.

In 2002, the main activities, in relative terms and in descending order of importance, of the farms were as follows: soybeans $(22.6 \%)$, cattle $(18.4 \%)$, and corn (13.7\%), which together accounted for approximately $55 \%$ of the total. Regarding the results for the sum of the farms, the most important were those whose main activities are related to cattle, soybeans, corn, vegetables, tobacco, and coffee. In 2014 there was a significant increase in the relative share of the following: cattle raising, which represented $35.7 \%$ of the total for the main activities conducted in the farms, corn $(14.0 \%)$, and soybeans $(11.3 \%)$, which together accounted for $61 \%$ of the total. These figures alone indicate that the composition of the main activities of the farms in the state of Paraná is mainly related to the beef and grain complexes, as already mentioned by Fuentes-Llanillo et al. (2006). 
The farms whose main activities are based on cattle raising or on other crops, achieved an increase of $3.7 \%$ pa and $3.6 \%$ pa, respectively, whereas those dedicated to other activities experienced decreases, with the largest observed in other temporary crops (-16.2\% pa), soybeans (-8.9\% pa), and corn (-6.3\% pa). Balsadi and Del Grossi (2016) observed a downward trend, between 2004 and 2014, for Brazil in the agricultural EAP engaged in soybean activities, as well as in crops such as rice, coffee, banana, sugarcane, cocoa, tobacco, citriculture and forestry, classified in this study as "other crops." Additionally, with regard to soybean, corn, and tobacco activities, the results found here are consistent with those shown by Maia and Sakamoto (2014), who observed a decrease, between 1992 and 2012 , in the number of farms dedicated to said crops in the South of Brazil.

With regard to the reduction in the number of farms dedicated to grain activities (specifically soybeans and corn), it must be noted that it has taken place in the context of important phenomena underlying the changes that occurred in the occupations of individuals in rural areas. These phenomena chiefly include the intensification of the mechanization of production and the introduction of increasingly labor-saving technologies, the emergence of new crops and varieties that require fewer agricultural operations in their management (FERREIRA et al., 2006), and the outsourcing of agricultural activities. This process in itself has already generated a natural selection of the more capitalized employers and self-employed individuals who are able to develop activities based on an increasingly modern agriculture. Furthermore, according to Sauer and Leite (2012a), the increase in the acquisition of land for agricultural production is related to commodities such as soybeans, corn, and sugarcane - in these activities there has been a concentration of land ownership. Thus, it is worthwhile noting that these trends are associated with both the land size of the farms and the main type of activity and that these are, in turn, linked to agribusiness dynamics. Furthermore, as Proni and Garrido (2005) highlighted, the advancement of the mechanization of agriculture and the adoption of new management strategies widens the gap between large and small farms, resulting in the concentration of land.

Table 3 shows the evolution in the number of farms in Paraná with land sizes of $\geq 0.1$ to $<10$ ha, $\geq 10$ to $<100$ ha, and $\geq 100$ ha, in accordance with the data of the PNAD from 2002 to 2014.

In absolute terms, between 2002 and 2006, most of the farms were concentrated in the land size category of $\geq 10$ to $<100$ ha, while from 2011 onwards, they were concentrated in the $\geq 0.1$ to $<10$ ha category. In any case, the results indicate that, on average, $95 \%$ of the farms were concentrated in the lower and intermediate categories.

In the land size category of $\geq 10$ to $<100$ ha, there was a $7.09 \%$ pa reduction in the number of farms, which is equivalent to an annual decrease of 6,184 farms on average.

In general, a downward trend was observed in the number of farms approximately 6,220 each year, or a reduction of $3.53 \%$ pa. These results are in accordance with those of Hoffmann and Ney (2010), who found a significant reduction in the number of farms in Brazil. This trend was observed by these authors in a more pronounced way after 1999, accelerating from 2004 onward. Moreover, the authors observed that, regarding the total number of farms, the smallest downward trend was observed for the South relative to the other large regions of the country between 1992 and 2008. The same has occurred in other countries (e.g., the US), where there has been a decline in the number of farms and an increase in land concentration (SUMNER, 2014). 
Table 3. Distribution of farms by land size category in rural Paraná between 2002 and 2014 (in thousands of farms).

\begin{tabular}{ccccc}
\hline \multirow{2}{*}{ Year } & \multicolumn{4}{c}{ Land size } \\
\cline { 2 - 5 } & $\geq 0.1$ to $<10$ ha & $\geq 10$ to $<100$ ha & $\geq 100$ ha & Total $(\geq 0.1)$ \\
\hline 2002 & 79.0 & 113.8 & 5.2 & 198.0 \\
2003 & 69.9 & 116.6 & 9.4 & 195.9 \\
2004 & 68.1 & 109.4 & 12.0 & 189.5 \\
2005 & 80.7 & 109.2 & 11.9 & 201.8 \\
2006 & 73.9 & 101.2 & 10.7 & 185.8 \\
2007 & 107.6 & 89.7 & 9.9 & 207.2 \\
2008 & 105.6 & 98.8 & 11.5 & 215.9 \\
2009 & 70.4 & 77.4 & 7.6 & 155.4 \\
2011 & 77.8 & 72.5 & 6.7 & 157.0 \\
2012 & 78.6 & 44.4 & 6.0 & 129.0 \\
2013 & 69.9 & 61.2 & 4.6 & 135.7 \\
2014 & 84.1 & 54.0 & 7.6 & 145.7 \\
$i^{1}$ & $0.317^{\mathrm{NS}}$ & $-7.087^{* * *}$ & $-3.642^{\mathrm{NS}}$ & $-3.531^{* * *}$ \\
\hline
\end{tabular}

Source: Prepared by the authors based on the microdata of the PNAD/IBGE from 2002 to 2014.

Notes: ${ }^{1}$ Mean annual growth rate expressed in percentage. Corresponds to the estimated coefficient of a log-linear regression against time. In this case, the $t$-test reveals whether there are trends in the data. *** indicates a level of significance of $1 \%$.

Table 4 shows the results concerning the share for the state of Paraná in the period from 2002 to of the number of farms per land size category (in 2014.

percentage) as well as the HHI concentration index,

Table 4. Share of the number of farms per land size category and HHI concentration index, for Paraná in the period from 2002 to 2014 (in \%).

\begin{tabular}{ccccc}
\hline \multirow{2}{*}{ Year } & \multicolumn{3}{c}{ Land size } & HHI \\
\cline { 2 - 4 } & $\geq 0.1$ to $<10$ ha & $\geq 10$ to $<100$ ha & $\geq 100$ ha & 0.49 \\
2002 & $39.90 \%$ & $57.47 \%$ & $2.63 \%$ & 0.48 \\
2003 & $35.68 \%$ & $59.52 \%$ & $4.80 \%$ & 0.46 \\
2004 & $35.94 \%$ & $57.73 \%$ & $6.33 \%$ & 0.45 \\
2005 & $39.99 \%$ & $54.11 \%$ & $5.90 \%$ & 0.46 \\
2006 & $39.77 \%$ & $54.47 \%$ & $5.76 \%$ & 0.46 \\
2007 & $51.93 \%$ & $43.29 \%$ & $4.78 \%$ & 0.45 \\
2008 & $48.91 \%$ & $45.76 \%$ & $5.33 \%$ & 0.45 \\
2009 & $45.30 \%$ & $49.81 \%$ & $4.89 \%$ & 0.46 \\
2011 & $49.55 \%$ & $46.18 \%$ & $4.27 \%$ & 0.49 \\
2012 & $60.93 \%$ & $34.42 \%$ & $4.65 \%$ & 0.47 \\
2013 & $51.51 \%$ & $45.10 \%$ & $3.39 \%$ & 0.47 \\
2014 & $57.72 \%$ & $37.06 \%$ & $5.22 \%$ & \\
\hline
\end{tabular}

Source: Based on the microdata of the National Household Sample Survey (PNAD) of the Brazilian Institute of Geography and Statistics (IBGE). 
There was a change in the composition of the farms. In 2002 the highest number of farms was in the $\geq 10$ to $<100$ ha range $(57.47 \%)$, followed by the $\geq 0.1$ to $<10$ ha range $(39.90 \%)$, and, finally, the $\geq 100$ ha range, which represented $2.63 \%$ of the farms. For the year 2014, the number of farms in the $\geq 0.1$ to $<10$ ha category increased to $57.72 \%$, in the $\geq 10$ to $<100$ ha category, it decreased to $37.06 \%$, and in the $\geq 100$ ha category, it increased to $5.22 \%$. This change in the composition of afarms was also observed by Adamopoulos and Restuccia (2014) and Lowder et al. (2016), who highlighted the increase in the number of farms with smaller landholdings in Brazil and worldwide.

According to Hoffmann and Ney (2010), the growth in the number of farms related to the smallest land size category was due to the increase in the number of properties designated for family agriculture, ${ }^{8}$ small farms, farms for leisure and housing for individuals who work in the city and do not depend on agriculture to survive.

Another hypothesis for the growth and maintenance of the number of farms belonging to the $\geq 0.1$ to $<10$ ha category was raised by Helfand et al. (2014): a significant minority of the small- and medium-sized farms are highly competitive, whereas the majority have difficulty generating income, with few alternatives outside the rural environment, which leads them to continue producing what they can.

Other possible reasons for the positive trend in the number of farms in the smallest land size category can be attributed to a variety of public policies (rural retirement, family allowance, Pronaf, etc.), which allow families to survive on agricultural activity even without full income generation (BUAINAIN; DEDECCA, 2010; ARAÚJO; ICHIKAWA, 2011; HELFAND et al., 2014).
In relation to the HHI concentration index, for Paraná the farms were considered to be highly concentrated; however, it must be emphasized that between 2002 and 2009, the concentration index decreased from 0.49 to 0.45 ; that is, during this period the HHI had a decreasing trajectory. However, between 2011 and 2014, the index changed its trajectory and started to increase, finishing at 0.47 by the end of 2014 .

Within the context of the large regions, the South has the lowest rates of land concentration in Brazil and, to a certain extent, the most economically developed regions have the best indicators, given that the rates become more unequal in the states with a low degree of economic development, i.e., the Center-West, North, and Northeast. Although the South is the "least concentrated," it must be emphasized that these differences are only valid for making relative comparisons because in general all Brazilian states have relatively high land concentration (ALCANTARA FILHO; FONTES, 2009). In fact, the state of Paraná follows the Brazilian trend, in which a high concentration of land ownership prevails (ALCANTARA FILHO; FONTES, 2009; HOFFMANN; NEY, 2010; SAUER; LEITE, 2012b).

The discussion on farms has increased in the global literature in recent times (NEY; HOFFMANN, 2008; EASTWOOD et al., 2010; HAZELL et al., 2010; DEININGER; BYERLEE, 2012; MASTERS et al., 2013; HLPE, 2013; ADAMOPOULOS; RESTUCCIA, 2014; LOWDER et al., 2016). The explanation for this is the importance of agricultural properties in economic and social development because, in addition to ensuring food security and the food supply, agricultural properties have a direct impact on social transformations - such as concentration of landholdings and rural exodus -

\footnotetext{
8 Family agriculture is defined by Law no. 11.326 of July 24, 2006, and requires the following of the farms: (i) uses family labor in the farm's activities, (ii) the family's income must be predominantly derived from the activities performed in the farm, and (iii) the farm must be managed by the family.
} 
within and away from the countryside. Researchers' concerns in addressing this topic in order to evaluate the possible transformations (or lack of) in farms worldwide emerge within this context.

According to Eastwood et al. (2010), the average size of properties increased in North America and Europe between 1950 and 1990, which explains the decline in the number of farms. According to Deininger and Byerlee (2012), one of the causes is the abundance of land in some countries, such as those in Latin America, Eastern Europe, and Central Asia. Another explanation was presented by Lowder et al. (2016), whereby the average size of the farms increased in most medium- to highincome countries and in almost all high-income countries. The explanation for this phenomenon is the relationship between the size of the farms and the opportunity cost of labor - as non-agricultural wages increase, the farms increase in size in order to equalize incomes between sectors of the economy (EASTWOOD et al., 2010).

However, the increase in the average size of farms is not a trend observed in all countries, given that between 1970 and 2000 there was a decrease in the average size of farms in most of the countries considered to be low- and middle-income - those in Africa, Asia, and Latin America (HAZELL et al., 2010; EASTWOOD et al., 2010; MASTERS et al., 2013; HLPE, 2013; LOWDER et al., 2016).

In the case of Brazil, Ney and Hoffmann (2008) analyzed the landholding structure and farms through the agricultural censuses (1995/96-2006) and showed that there was landholding inequality in the country, which remained stable over time, and a decline in the average area of farms. According to the authors, what actually occurred was an increase in the number of farms with less than 10 ha, while there was a clear decrease in the number of farmers with a land area greater than 100 ha. Thus, the number of farms is directly related to the population level of rural areas. According to Hoffmann and Ney (2010), data from the most recent Agriculture Census of 2006 indicate a high level of inequality in the distribution of land ownership in Brazil, characterized by the huge proportion of total agricultural area occupied by farms with land sizes $\geq 1,000$ ha. According to the authors, these represent only $0.95 \%$ of the total number of farms in the country but occupy $44.4 \%$ of the total area, whereas those with land size $<10$ ha represent $50.3 \%$ of the farms but occupy only $2.4 \%$ of the total area. In Paraná, the data from the PNAD indicated an increase in the proportion of farms with land area $<10$ ha from $39.90 \%$ in 2002 to $57.72 \%$ in 2014 - an increase of approximately 45\%; however, the proportion of farms with land area $>100$ ha was only $5.22 \%$ in 2014 . These results show that there is a large number of farms with small land areas and a very small number that have larger land areas. These findings highlight the enormous land inequality in both Brazil and in the state of Paraná.

\section{Final considerations}

According to the total land size category in the period between 2002 and 2014, the estimated mean annual rates of change in the distribution of the most frequent activities in farms belonging to employers and self-employed individuals in Paraná indicated that except for cattle raising, which showed slight growth, there was a reduction for all activities, which was more accentuated for temporary crops.

Regarding the distribution of employer and self-employed farms per land size category, it was observed that the intermediate category (between 10 and $100 \mathrm{ha}$ ) had the highest percent share and that the number of farms in this category decreased over time. This was followed by the lower land size category of 0.1 to 10 ha with a slight increase in annual growth rates. Finally, the upper land size category (greater than $100 \mathrm{ha}$ ) represented the minority of the farms and experienced a decrease in annual growth rates. Thus, in the state of Paraná, the farms in the lower land size category, which are considered to be small in size and predominantly family-owned, prevail. 
Furthermore, it is plausible to assume that the increase in the number of farms in the lower land size category may be associated with the increase in cattle-raising activity, especially milk production, resulting from the increase in the number of small family-owned farms.

In this context, the results presented here can more objectively support the formulation of public actions focused on each of the agricultural sectors and on land distribution in the state of Paraná.

\section{References}

ADAMOPOUlOS, T.; RESTUCCIA, D. The size distribution of farms and international productivity differences. The American Economic Review, Nashville, v. 104, n. 6, p. 1667-1697, 2014.

AlCANTARA FIlHO, J. L.; FOnTES, R. M. O. A formação da propriedade e a concentração de terras no Brasil. Revista de História Econômica \& Economia Regional Aplicada, Juiz de Fora, v. 4, n. 7, p. 63-85, 2009.

ARAÚJO, E. J. C.; ICHIKAWA, E. Y. Compreendendo o projeto de redes de referência para agricultura familiar a partir das representações sociais dos atores envolvidos. Organizações Rurais \& Agroindustriais, Lavras, v. 13, n. 1, p. 39-52, 2011.

BALSADI, O. T. Trabalho e emprego na agricultura sulina em 2004-2014. Revista Política Agrícola, Brasília, v. 26, n. 4, p. 35-49, 2017.

BALSADI, O. V. Evolução das ocupações e do emprego na agropecuária do centro-oeste brasileiro no período 2001-05. Revista Informações Econômicas, São Paulo, v. 39, n. 1, p. 32-40, 2009.

BALSADI, O. V.; DEL GROSSI, M. E. Trabalho e emprego na agricultura brasileira um olhar para o período 2004-2014. Revista de Política Agrícola, Brasília, v. 25, n. 4, p. 82-96, 2016.

BAZOTTI, A.; NAZARENO, L. R.; CINTRA, A. P. U. Um ensaio sobre as famílias agrícolas paranaenses a partir das PNADs 1992, 1998, 2005 e 2007. Revista Paranaense de Desenvolvimento, Curitiba, v. 30, n. 117, p. 123-145, 2009.

BOFF, H.; RESENDE, M. Concentração industrial. In: HASENCLEVER, L.; KUPFER, D. (Org.). Economia industrial: fundamentos teóricos e práticos no Brasil. Rio de Janeiro: Campus, 2002. p. 73-90.
BUAINAIN, A. M.; DEDECCA, C. S. Mudanças e reiteração da heterogeneidade do mercado de trabalho agrícola. In: GASQUES, J.; VIEIRA FILHO, J.; NAVARRO, Z. (Org.). A agricultura brasileira: desempenho, desafios e perspectivas. Brasília: IPEA, 2010. p. 123-156.

COSTA JUNIOR, G.; BACHA, C. J. C. Análise do pessoal ocupado no meio rural do Paraná de 2000 a 2010. Revista Pesquisa \& Debate, São Paulo, v. 27, n. 1, p. 91107, 2016.

DEININGER, K.; BYERLEE, D. The rise of large farms in land abundant countries: do they have a future? World Development, Oxford, v. 40, n. 4, p. 701-714, 2012.

DEL GROSSI, M.; GRAZIANO DA SILVA, J. Mudanças recentes no mercado de trabalho rural. Parcerias Estratégicas, Brasília, v. 11, n. 22, p. 201-216, 2006.

EASTWOOD, R.; LIPTON, M.; NEWELL, A. Farm size. In: PINGALI, P. L.; EVENSON, R. E. (Ed.). Handbook of agricultural economics. Elsevier: North Holland, 2010. v. 4, p. 3323-3397.

FERREIRA, B.; BALSADI, O. V.; FREITAS, R. E.; ALMEIDA, A. N. Ocupações agrícolas e não agrícolas: trajetória e rendimentos no meio rural brasileiro. In: DE NEGRI, J. A.; DE NEGRI, F.; COELHO, D. (Org.). Tecnologia, exportação e emprego. Brasília: IPEA, 2006. p. 445-488.

FUENTES-LLANILLO, R.; DEL GROSSI, M. E.; SANTOS, F. O.; MUNHOS, P. D.; GUIMARÃES, M. F. Regionalização da agricultura do Estado do Paraná, Brasil. Ciência Rural, Santa Maria, v. 36, n. 1, p. 120127, 2006.

GREENE, W. H. Econometric analysis. $6^{\text {th }}$ ed. Upper Saddle River: Prentice Hall, 2008. 1216 p.

HAZELL, P.; POULTON, C.; WIGGINS, S.; DORWARD, A. The future of small farms: trajectories and policy priorities. World Development, Oxford, v. 38, n. 10, p. 1349-1361, 2010.

HELFAND, S.; PEREIRA, M.; SOARES, W. Pequenos e médios produtores na agricultura brasileira: situação atual e perspectivas. In: BUAINAIN, A. M.; ALVEZ, E.; SILVEIRA, J. M.; NAVARRO, Z. (Org). O mundo rural no Brasil do século XXI: a formação de um novo padrão agrário e agrícola. Brasília: EMBRAPA, 2014. p. 533-558.

HIGH LEVEL PANEL OF EXPERTS ON FOOD SECURITY AND NUTRITION - HLPE. Investing in smallholder agriculture for food security. Rome: FAO, 2013. 
HIRSCHMAN, A. O. The paternity of an index. The American Economic Review, Nashville, v. 54, n. 5, p. 761-762, 1964.

HOFFMANN, R. Distribuição da renda agrícola e sua contribuição para a desigualdade de renda no Brasil. Revista de Política Agrícola, Brasília, v. 20, n. 2, p. 5-22, 2011.

HOFFMANN, R.; NEY, M. G. Estrutura fundiária e propriedade agrícola no Brasil, grandes regiões e unidades da federação. Brasília: Ministério do Desenvolvimento Agrário, 2010. 108 p.

LAURENTI,A.C. Evolução da ocupação e do rendimento das pessoas no meio rural do Paraná no período 20012009. Revista Paranaense de Desenvolvimento, Curitiba, v. 34, n. 124, p. 175-199, 2013.

LAURENTI, A. C.; PELlini, T.; TElles, T. S. Evolução da ocupação e do rendimento das pessoas no espaço rural brasileiro no Período de 2001 a 2009. Revista de Economia e Sociologia Rural, Curitiba, v. 54, n. 2, p. 321-342, 2015.

LOWDER, S. K.; SKOET, J.; RANEY, T. The number, size, and distribution of farms, smallholder farms, and family farms worldwide. World Development, Oxford, v. 87, p. 16-29, 2016.

MAIA, A. G.; BUAINAIN, A. M. O novo mapa da população rural brasileira. Confins, Paris, n. 25, p. 1-26, 2015.

MAIA, A. G.; SAKAMOTO, C. S. A nova configuração do mercado de trabalho agrícola brasileiro. In: BUAINAIN, A. M.; AlVES, E.; SIlvEIRA, J. M.; NAVARRO, Z. (Org.). O mundo rural no Brasil do século 21: a formação de um novo padrão agrário e agrícola. Brasília: EMBRAPA, 2014. p. 591-619.

MASTERS, W. A.; DJURFELDT, A. A.; DE HAAN, C.; HAZELL, P.; JAYNE, T.; JIRSTRO, M.; REARDON, T. Urbanization and farm size in Asia and Africa: implications for food security and agricultural research. Global Food Security, Amsterdam, v. 2, n. 3, p. 156-165, 2013.

MATTEI, L. Emprego agrícola: cenários e tendências. Estudos Avançados, São Paulo, v. 29, n. 85, p. 35-52, 2015.

NEDER, H. D. Estrutura do mercado de trabalho agrícola no Brasil: uma análise descritiva da evolução de suas categorias entre 1995 e 2006. In: BUAINAIN, A. M.; DEDECCA, C. (Org.). Trabalho e emprego na agricultura brasileira. Brasília: IICA, 2008. p. 156-182.
NEY, M. G.; HOFFMANN, R. A contribuição das atividades agrícolas e não-agrícolas para a desigualdade de renda no Brasil rural. Economia Aplicada, Ribeirão Preto, v. 12, n. 3, p. 365-393, 2008.

Desigualdade de renda na agricultura: o efeito da posse da terra. Economia, Niterói, v. 4, n. 1, p. 113$152,2003$.

PRONI, M. W. Mapeamento do trabalho agrícola no Brasil. In: MORETTO, A.; KREIN, J. D.; POCHMANN, M.; MACAMBIRA, J. (Org.). Economia, desenvolvimento regional e mercado de trabalho do Brasil. Fortaleza: Instituto de Desenvolvimento do Trabalho, Banco do Nordeste do Brasil, Centro de Estudos Sindicais e de Economia do Trabalho, 2010. p. 139-176.

PRONI, M. W.; GARRIDO, F. L. Agricultura, desigualdade regional e trabalho no Brasil. Revista da ABET, João Pessoa, v. 5, n. 1, p. 219-247, 2005.

RESENDE, M. Medidas de concentração industrial: uma resenha. Revista Análise Econômica, Porto Alegre, v. 12, n. 21-22, p. 24-33, 1994.

SAKAMOTO, C. S.; MAIA, A. G. Dinâmica do mercado de trabalho agrícola e impactos sobre a distribuição de rendimentos nos anos 2000. Revista da ABET, João Pessoa, v. 11, n. 2, p. 11-31, 2012.

SAUER, S.; LEITE, S. P. Agrarian structure, foreign investment in land, and land prices in Brazil. The Journal of Peasant Studies, Londres, v. 39, n. 3-4, p. 873-898, 2012 b.

Expansão agrícola, preços e apropriação de terra por estrangeiros no Brasil. Revista de Economia e Sociologia Rural, Piracicaba, v. 50, n. 3, p. 503-524, $2012 \mathrm{a}$.

STADUTO, J. A. R.; NASCIMENTO, C. A.; SOUZA, M. Ocupações e renda das mulheres e homens no rural do estado do Paraná, Brasil: uma perspectiva de gênero. Cuadernos de Desarrollo Rural, Santafé de Bogotá, v. 10, n. 72, p. 91-115, 2013.

SUMNER, D. A. American farms keep growing: size, productivity, and policy. Journal of Economic Perspectives, Nashvile, v. 28, n. 1, p. 147-166, 2014.

TElleS, T. S.; COSTA, G. V.; BACCHI, M. D.; LAURENTI, A. C. Evolução da população rural ocupada nas Grandes Regiões do Brasil entre 2001 e 2009. Interações, Campo Grande, v. 18, n. 1, p. 17-26, 2017. 